\title{
Student Role Supports for Younger and Older Middle- Aged Women: Application of a Life Event Model
}

\section{Charlene Thacker* and Mark Novak•}

\section{ABSTRACT}

This paper is a report on a study of 276 women aged 35 to 64 who have reentered university. We used the life-event framework to focus on the stress of university life, on the methods these women use to cope with stress and on their adaptations to the demands of school. We compared the re-entry experience of two sub-groups in our population: students aged 35 to 44 (with young families) and those aged 45 to 64 (with mature families). We found that each group had different motives for attending school, each group felt different strains during the school year and each group used different methods and resources to cope with the demands of student life. The paper concludes with a review of the literature on programs that meet the needs of re-entry women. We note the applicability of these programs to the distinct needs of younger and older reentry women and we encourage the development of more programs to meet both groups' needs.

\section{RÉSUMÉ}

Cet article rend compte d'une étude menée à partir du témoignage de 276 femmes de 35 à 64 ans qui ont repris des études universitaires. Nous avons eu recours à une approche tenant compte des cycles de la vie pour analyser le montant de stress généré chez ces femmes par la vie universitaire et pour mettre en lumière les méthodes que celles-ci utilisent pour faire face à ce stress et s'adapter aux exigences propres aux études universitaires. Nous avons ce faisant comparé cette expérience au sein de deux sous-groupes: d'une part les étudiantes âgées de 35 à 44 ans, mères de jeunes enfants, et d'autre part celles de 45 à 64 ans dont les enfants avaient atteint l'âge adulte. Nous avons découvert que les raisons qui poussaient les personnes de ces deux groupes à reprendre des études étaient très différentes de même que les difficultés qu'elles

* Associate Professor, Dept. of Sociology, University of Winnipeg

- Professor, Continuing Education Division, University of Manitoba 
éprouvaient pendant l'année scolaire et les moyens qu'elles utilisaient pour être à la hauteur de ce qu'on exigeait d'elles en tant qu'étudiantes. Cet article présente ensuite un éventail de programmes parmi ceux qui répondent le mieux aux besoins des femmes qui reprennent des études. Nous y soulignons dans quelle mesure ces programmes conviennent aux besoins spécifiques soit des femmes les plus jeunes soit des femmes les plus âgées et nous sollicitons la création d'un plus grand nombre de programmes susceptibles de répondre aux besoins des deux groupes.

\section{Introduction}

More adults than ever before attend post-secondary institutions (Campbell, 1984) and even greater numbers of adults will attend school in the future (Breneman, 1983; Crimmins \& Riddler, 1985; Frances, 1980; Glenny, 1980). A Carnegie Council report (1981) projects a decrease in the proportion of traditional-aged students (18-24 years old) in the U.S. The report states that, by the year 2000, as many higher education students will be over 21 years old as will be 21 years or younger. Campbell (1984, p.14) calls Canadian adult learners taking part-time credit and formal non-credit University courses the "new majority" because by 1974-75 they outnumbered full-time University students.

Belanger and Omiecinski (1987) report that Canadian adult students aged 2544 more often than younger students attend school part-time. A recent Canadian survey (Devereaux, 1985) reports that one in five adults (aged 17+) took some part-time education. Universities provided about $11 \%$ of these courses. The same survey found a high interest in organized education among adult women. Among part-time students, about one woman in three aged 25-34 took some form of adult education.

In 1984-85, women made up $61 \%$ of the Canadian part-time university undergraduate population (Parliament, 1986). In every age category, women constituted the majority of part-time students. They made up about $70 \%$ of parttime students aged 45 and over (Belanger \& Omiecinski, 1987).

These trends will grow stronger as more women enter the labour force. A woman today can expect to work forty years of her adult life, with ten years taken out to raise children (Shuster \& Van Dyne, 1985). Research shows that women often decide to return to school for work-related reasons (Apps, 1981; Astin, 1976; Felmlee, 1988; McCrea, 1979; Smart \& Pascarella, 1987). Our data indicate that this applies especially to younger re-entry women.

In this paper we focus on middle-aged re-entry women. We use a life event perspective to understand and describe their institutional support needs. 


\section{The Life Event Framework}

According to the life event framework, life events - stresses from the environment or life crises-create individual strain and lead to adaptation or change. Hultsch and Deutsch (1981) describe three types of life events: normative age-graded events, non-normative events and historical events. Normative age-graded events include the launching of a woman's last child or the start of retirement. Non-normative events include a sudden illness or a natural disaster. Historical events include the end of the Second World War or an economic depression.

Critics of stress studies say that they focus too much on external events (Mechanic, 1974). They view the individual as a passive object in a world of external change. Change, in the life event framework, comes about when something disturbs a person's equilibrium and the person has to adapt. This view overlooks the person's ability to take an active role in the environment and to initiate change.

In mid-life people often choose to change. They look for variety, challenge and a chance for personal growth. This shows up as a search for new work, new relationships and a new sense of self. Studies in the past few years have reported on this inner drive to change in middle-age (Gould, 1978; Levinson, 1978; Sheehy, 1976, 1981). We consider life events occasioned by this inner desire to change as a fourth type of life event: a self-initiated life event.

Self-initiated life events include the return to work of a woman as her children grow older and the return of middle-aged women to university. This type of life event can create stress as great or greater than the other types of life events. In this case, however, the person seeks the life event because it leads to growth. Selye (1975) calls the stress that comes from this kind of life event eustress or positive stress. People need this kind of stress or challenge in order to develop new skills, knowledge and relationships.

The life event framework provides a model for studying life events. Figure 1 presents this framework.

Our usage of terms in the model follows generally that of Whitbourne (1985).

This model (Figure 1) includes:

1. The Life Event - the internal or external demand that challenges the person to change.

2. Stress - the effect on the person of the life event. Following Lazarus (1981), Whitbourne (1985) conceptualizes stress as the demands that impact upon available resources in such a way as to exceed, or at least tax, available 
Figure 1. Life Event Model

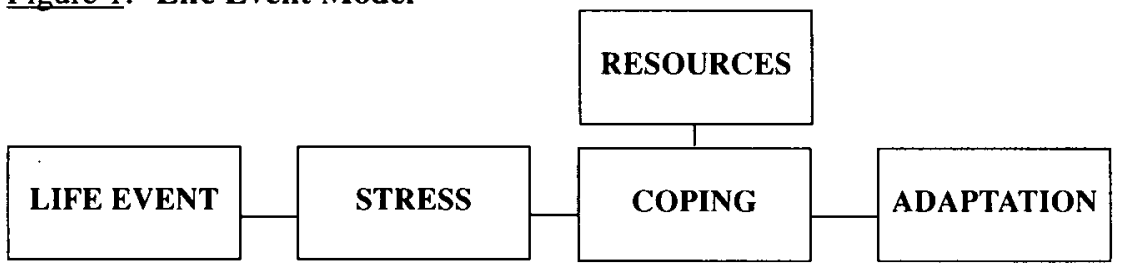

Figure 1. The life event model of adaptation. From "The Psychological Construction of the Life Span" by S.K. Whitbourne, 1985, in J.E. Birren, K.W. Schaie, Handbook of the Psychology of Aging. New York: Van Nostrand Reinhold, p. 600. Copyright, 1985, Van Nostrand Reinhold. Reprinted by permission.

resources. The same objective stress may cause different feelings of strain (or no strain at all) in different people.

3. Coping - the way a person responds to a life event. Whitbourne (1985) uses Pearlin and Schooler's (1978) definition of coping as "any response to external life strains (stresses in our model) that serves to prevent, avoid, or control emotional distress (Pearlin and Schooler, 1978, p.3). Coping can include a redefinition of the life event, the denial of the life event or the use of resources to respond to the life event.

4. Resources - George (1980) defines personal resources as "the broad range of reserves and aids individuals can draw on in times of need" (p.25). Personal resources include health, education, finances and social supports. Lin, Simeone, Ensel, and Kuo (1979) define social supports as "support accessible to an individual through social ties to other individuals, groups, and the larger community" (p. 109). George (1980) includes status variables, such as occupation and ethnicity, as well as socialization experiences, in the discussion of social resources.

5. Adaptation - the outcome of the person's response to the life event. How a person adapts depends on the person's coping response to the life event and on the person's resources.

This study describes the return to school of middle-aged women as a selfinitiated life event. This life event leads to stress. It also leads women to use resources like social and psychological supports in order to adapt. We have produced an elaborated Life Event Model for use in this study (Figure 2). We apply this model to educational re-entry and include the measures used for each concept. 
Figure 2. Life Event Model

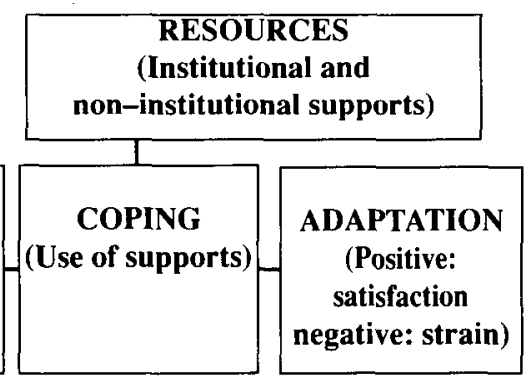

Figure 2. Educational re-entry: Elaborated life event model with measures. Adapted and elaborated from "The Psychological Construction of the Life Span" by S.K. Whitbourne, 1985, in J.E. Birren, K.W. Schaie, Handbook of the Psychology of Aging. New York: Van Nostrand Reinhold, p. 600. Copyright, 1985, Van Nostrand Reinhold. Reprinted by permission.

\section{Re-entry as a Self-Initiated Life Event}

"In current Western society," Brooks-Gunn and Kirsh (1984) say, "midlife is often thought to begin at age 35" (p. 12). This means that middle age in North America covers nearly 30 years (roughly from age 35 to 65). This period includes many life-cycle stages (Riegel, 1975). Parenting, for example, affects a woman's experience differently at different points in mid-life. At 35 , a woman may have one or more young children to care for. At 50, a woman may have no children in the home.

Brooks-Gunn and Kirsh (1984) caution that many of the life events associated with mid-life are associated only in a probabilistic sense. All individuals do not experience them, or experience them at different times or in a different sequence. Still, for most women, parental and occupational responsibilities give normative structure to mid-life (Neugarten \& Datan, 1973).

We define a life-cycle stage as the array of commitments and responsibilities a person feels to family and work at a given time, based on social norms and on the expectations that others have of that person. This definition describes the concept of a life-cycle stage in terms of a person's social roles. It also emphasizes the person's feelings of commitment and responsibility to those roles. These feelings may lead to strain when a person faces competing role demands. 
Family responsibilities, for example, may create an added source of stress (in addition to school-related stress) for re-entry women. Gore (1984) calls this source of stress, "life circumstances or conditions" (p. 205). These life conditions differ for women at different points in the life cycle. A married mother in her early $30 \mathrm{~s}$, for example, may return to school to complete her unfinished degree. She will likely feel a strong commitment to care for her husband and her children. She may also feel a strong commitment to a job and fellow workers. A single woman of this same age may return to school to improve her career options. She will probably feel less pressure to care for other family members. She may focus her commitments more on her job and personal relationships. Finally, a married woman in her 50s may return to school to get back into the work force. She will likely feel less commitment to daily care for children, but she may feel a commitment to care for aging parents and in-laws. She may also have more time and energy than the young mother to commit to her career.

Some research on re-entry women supports the idea that these students differ by life-cycle stage (Campbell, Wilson \& Hanson 1980). Carp, Peterson, \& Roelfs (1976) studied potential re-entry women (women who did not attend school, but said they might like to attend). They found that $46 \%$ of potential learners gave lack of time as a reason for not going to school, $28 \%$ gave job responsibilities and $32 \%$ gave home responsibilities. Other studies also indicate that family responsibilities interfere with educational goals and commitments (see Schlossberg, 1984).

Life cycle theory and some research suggests that a woman's life-cycle stage affects the amount and type of strain she feels when she returns to school. Her life-cycle stage may also affect how much help she needs and the types of resources she can call on to cope with stress. This study will focus on mid-life women in two life-cycle stages: younger women (aged 35-44) with young familes and older women (aged 45-64) with older families. We use the life event framework to compare the motivations, stresses and resources of these two groups. We conclude with a discussion of how universities can meet the diverse needs of middle-aged women.

\section{Findings}

The University studied is an urban university with approximately 8,000 students (about 3,200 full-time) in a medium-sized (population approximately 660,000) mid-western, Canadian city. In 1986 a questionnaire was sent to all 416 firstyear women aged 35 and over. All of these women had fewer than 5.5 course 
19 Student Role Supports for Younger and Older Middle-Aged Women:

Application of a Life Event Model

credits. After two follow-up contacts by mail, 276 usable questionnaires were received. This constitutes a $66.3 \%$ response rate.

The re-entry women in the study reported a mean family income of between $\$ 30,000$ and $\$ 39,000$ per year. Forty-seven percent of the students reported an annual family income between $\$ 30,000$ and $\$ 60,000$. The median age of these women was 41 years; and their ages ranged from 35 to 64 years. Sixty-eight percent were married. The median number of children for this group was two. The mean age of the youngest child was 14.76 years; and children ranged in age from one to 40 years.

Sixty-nine percent of these women worked full or part-time. The median number of years since these women last enrolled in a course before entering this University for the first time was 12 years. Almost half (49.3\%) of them had either some non-university or post-secondary education before enrolling.

We divided our population into two groups. One group consisted of women between the ages of 35 and 44 . The other group consisted of women between the ages of 45 and 64 . We then compared these groups on selected demographic variables. Table 1 compares these two groups.

Table 1

Characteristics of Younger and Older Middle-Aged Re-Entry Women

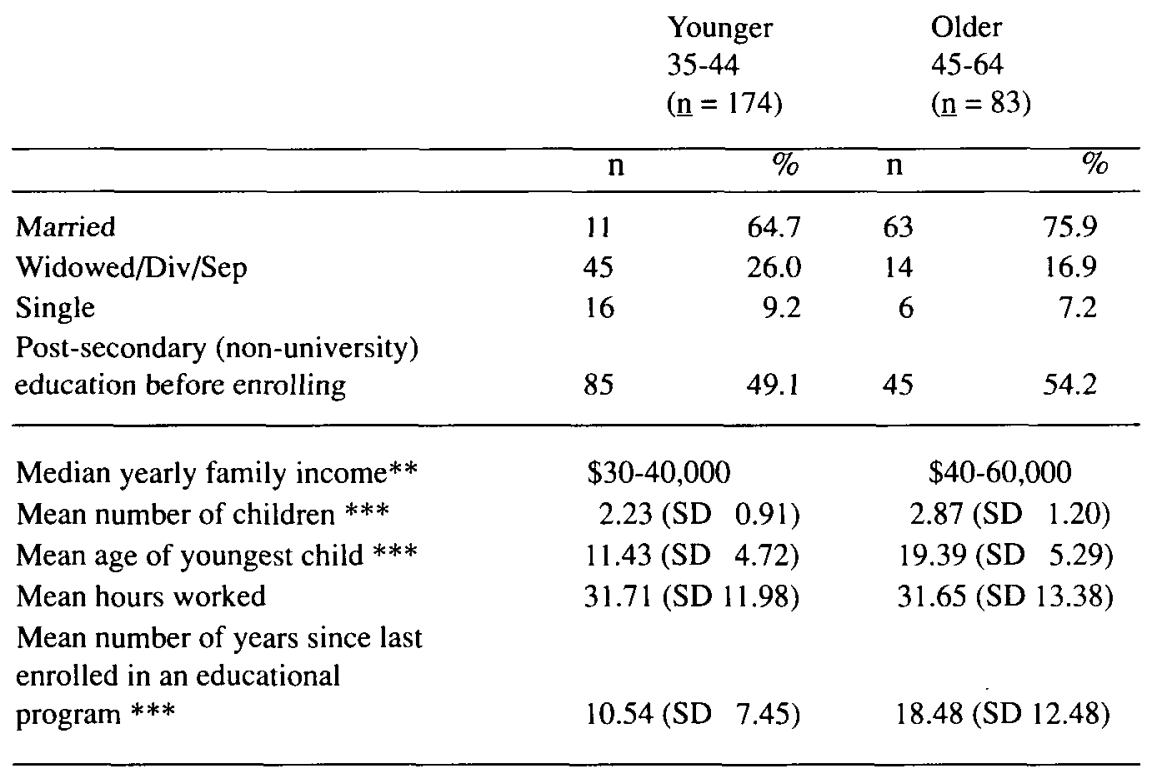

Significance levels: ${ }^{* *} \mathrm{p}<.01 ; * * * \mathrm{p}<.001$ 
Statistical tests of the differences of means between these goups showed that they differed significantly on some variables. The younger group had attended school more recently than the older groups and they had a lower family income than the older group. The younger group also tended to have fewer children and younger children. These findings suggest that the two groups were at different stages in the life-cycle.

We compared the two groups on a number of variables organized according to the life event framework (see Figure 2): (1) motivations for re-entry (the selfinitiated life event); (2) impact of re-entry on the person (stress); (3) supports known about and used (resources and coping); and (4) adaptation (satisfaction and strain).

\section{Motivations for Re-Entry}

Table 2 reports a comparison of the reasons younger and older re-entry women returned to school.

Table 2

Differences in Motivation for Re-entry Between Younger and Older MiddleAged Re-entry Women

\begin{tabular}{lccccc}
\hline Variable + & \multicolumn{2}{c}{ Younger } & \multicolumn{2}{c}{ Older } \\
& Mean & SD & \multicolumn{2}{c}{$\begin{array}{c}(45-64) \\
\text { Mean }\end{array}$} & SD \\
\hline Achieve independence** & 1.24 & 0.43 & 1.10 & 0.30 \\
Advancement in work** & 1.42 & 0.49 & 1.24 & 0.43 \\
Escape boredom & 1.16 & 0.36 & 1.11 & 0.31 \\
Find interests outside the home & 1.29 & 0.45 & 1.39 & 0.49 \\
Get degree** & 1.67 & 0.47 & 1.51 & 0.50 \\
Intellectual challenge* & 1.70 & 0.46 & 1.83 & 0.38 \\
Meet people & 1.17 & 0.37 & 1.24 & 0.43 \\
New career*** & 1.47 & 0.50 & 1.20 & 0.41 \\
New skills* & 1.44 & 0.50 & 1.29 & 0.46 \\
Self-development & 1.85 & 0.36 & 1.84 & 0.37 \\
& & & & \\
\hline
\end{tabular}

Significance levels: ${ }^{*} \mathrm{p}<.05 .{ }^{* *} \mathrm{p}<.01 .{ }^{* * *} \mathrm{p}<.001$.

+ Students answered Yes (2) or No (1) to each motivation item. The higher the score, the greater the proportion of students who reported this motivation. 
Both younger and older women have chosen to re-enter school. However, as Table 2 shows, younger and older women attend school for somewhat different reasons. Older women are more likely to return to school for the intellectual challenge and they report less concern about getting a degree. Younger women have more pragmatic reasons for returning to school. For one thing, younger women attend school to get a degree. They want to gain independence, get new skills and to either change careers or advance in their work.

\section{Impact of Re-entry on the Person}

Table 3 presents the differential impact of re-entry on younger and older women.

Table 3

Differences in Impact of Re-entry On Younger and Older Middle-Aged Reentry Women

\begin{tabular}{lllll}
\hline Variable + & $\begin{array}{l}\text { Younger } \\
(35-44) \\
\text { Mean }\end{array}$ & SD & $\begin{array}{l}\text { Older } \\
(45-64) \\
\text { Mean }\end{array}$ & SD \\
\hline $\begin{array}{l}\text { 1. Educational satisfaction } \\
\quad \text { at this University ** }\end{array}$ & 5.40 & 1.02 & 5.80 & 0.92 \\
$\begin{array}{l}\text { 2. Satisfaction with past } \\
\quad \text { educational experience*** }\end{array}$ & 4.91 & 1.77 & 5.83 & 1.13 \\
3. Family satisfaction & 5.19 & 1.28 & 5.48 & 1.25 \\
4. Feeling about attending & & & & \\
$\quad$ University & 4.49 & 0.62 & 4.55 & 0.55 \\
5. Health satisfaction & 5.02 & 1.17 & 5.33 & 1.24 \\
6. Hours spent on & & & & \\
$\quad$ school work** & 16.96 & 13.05 & 13.31 & 7.54 \\
7. Job satisfaction & 4.88 & 1.26 & 5.03 & 1.43 \\
8. Marital satisfaction & 4.16 & 0.84 & 4.10 & 1.13 \\
9. Marital strain* & 1.82 & 1.47 & 1.34 & 1.38 \\
10. Parental satisfaction & 4.17 & 0.85 & 4.22 & 0.86 \\
11. Parental strain*** & 2.39 & 1.45 & 1.24 & 1.29 \\
12. Relationship with children & 1.55 & 0.50 & 1.43 & 0.50 \\
13. Satisfaction with grades & 3.66 & 1.06 & 3.76 & 0.89 \\
14. Satisfaction with life* & 5.21 & 1.17 & 5.51 & 1.06 \\
15.School adds to time & & & & \\
$\quad$ pressure*** & 5.03 & 1.65 & 4.04 & 2.03 \\
16. Work strain** & 2.04 & 1.53 & 1.46 & 1.52 \\
\hline Significance levels**p* & & & & \\
\hline
\end{tabular}

Significance levels: ${ }^{*} \mathrm{p}<.05 .{ }^{* *} \mathrm{p}<.01 .{ }^{* * *} \mathrm{p}<.001$

+ Students rated all items (except 6 and 12) on Likert-type scales. The higher the values, the more positive the response. Relationship with children was scored Yes (2) or No (1). Hours spent on school work was scored in number of hours. 
From Table 3, it becomes apparent that younger and older re-entry women face somewhat different stresses. First, younger women report less satisfaction with their education at University. They also report significantly less enjoyment of past educational experiences. Younger women compared to older women tend to report less life satisfaction in general. Younger women report more strain in all spheres of life than do older women. They report more marital strain, more work strain and more parental strain. Younger women spend more time on school work; and they feel that school adds to their time pressure.

\section{Supports Known or Used}

Cross (1981) describes three types of barriers re-entry women face: situational, institutional and dispositional. Situational barriers include such things as family responsibilities and lack of money. Institutional barriers include the lack of evening classes and the absence of financial aid. Dispositional barriers have to do with attitudes of the learner. Supports aiding re-entry women to overcome these barriers may also be categorized under these headings. Table 4 reports a comparison of some institutional and situational (non-institutional) supports known to or used by younger and older re-entry women.

Table 4 shows significant differences between older and younger women on only two types of institutional support. First, older women more than younger women report the helpfulness of night courses. Second, older women tend to be more aware of mature student orientation sessions. In general, more younger women say they want more institutional supports. However, this finding failed to reach the 0.05 level of significance $(p<0.062)$.

Table 4 omits one important finding about institutional supports for mature re-entry women. Few members of either group use financial aid or social supports offered by the university. For example, only about $20 \%$ of younger and $17 \%$ of older women attended a mature student orientation session. The table omits comparisons of many financial and other institutional supports because too few students used these services to perform valid statistical tests of group differences.

Younger and older women have different kinds of family supports. First, younger women spend about five times more hours on child care per week while attending school than older women (20.48 hours and 3.94 hours respectively). This means that they need more child care help to find time for school. Some of this help comes from their spouses. Younger women report more help from spouses with child care. Younger women, compared to older women, more often turn to paid help to care for their children. In addition, older 
23 Student Role Supports for Younger and Older Middle-Aged Women:

Application of a Life Event Model

women had fewer young children who needed either spousal or paid child care. Older women report more positive feelings, as well as more psychological support from their children regarding their mothers' return to school.

Table 4

Differences in Supports Known to or Used By Younger and Older Middle-Aged Re-entry Women

\begin{tabular}{|c|c|c|c|c|}
\hline \multirow[t]{2}{*}{ Variable + } & \multicolumn{2}{|l|}{$\begin{array}{l}\text { Younger } \\
(35-44)\end{array}$} & \multicolumn{2}{|c|}{$\begin{array}{l}\text { Older } \\
(45-64)\end{array}$} \\
\hline & Mean & $\mathrm{SD}$ & Mean & SD \\
\hline
\end{tabular}

\section{Institutional Supports}

1. Aware of mature student orientation sessions*

$\begin{array}{llll}1.47 & 0.50 & 1.60 & 0.49 \\ 3.61 & 1.16 & 3.70 & 1.23 \\ 3.88 & 1.37 & 4.37 & 1.10 \\ 1.37 & 0.48 & 1.25 & 0.43\end{array}$

2. Professors' help

0.48

1.25

0.43

Non-Institutional Supports

5. Children take courses at university***

0.40

1.71

0.46

6. Childrens' feeling about return to school***

0.86

4.35

0.80

7. Childrens' help with childcare

1.18

0.39

1.17

0.38

8. Childrens' help with housework 1.60

0.49

1.49

0.50

9. Childrens' psychological support***

10. Family help with housework

11. Friends' feelings about return to school

12. Friends' help with childcare

13. Helpful students

14. Hours per week spent on child care during school $^{* *} \quad 20.48$

15. Paid help with childcare*

16. Paid help with housework

17. Spouse's help with child care** 1.58

18. Spouse's psychological support 3.33

21. Support from friends

$\begin{array}{crr}\text { outside school } & 3.15 & 1.3 \\ \text { Significance levels: }{ }^{*} \mathrm{p}<.05 . & { }^{* *} \mathrm{p}<.01 . & { }^{* * *} \mathrm{p}<.001\end{array}$
value, the more positive the response. Students answered all other items (except 14) Yes (2), No (1). 


\section{Adaptation}

The life event framework views adaptation as a return to equilibrium after a stressful life event. Our revised version of this framework states that in mid-life people may create life events for themselves so that they can develop. These life events can produce as much stress and as much need for coping and adaptation as other types of life events. We have operationalized positive adaptation as satisfaction in the student role and difficulties with adaptation as strain in the student role.

Table 5 reports a comparison of the satisfaction and strain that younger and older re-entry students feel in the student role.

\section{Table 5}

Differences in Satisfaction and Strain in the Student Role Reported By Younger and Older Middle-Aged Re-entry Women

\begin{tabular}{lllll} 
Variable & Younger & \multicolumn{2}{c}{ Older } \\
& $(35-44)$ & \multicolumn{2}{c}{$(45-64)$} \\
& Mean & SD & Mean & SD \\
\hline Satisfaction $* *$ & 3.82 & 0.96 & 4.15 & 0.82 \\
Strain*** & 3.29 & 1.13 & 2.60 & 1.38 \\
\hline
\end{tabular}

Significance levels: $\quad{ }^{* *} \mathrm{p}<.01 .{ }^{* * *} \mathrm{p}<.001$

+Students rated items on a Likert-type scale. The higher the value the greater the feeling of satisfaction or strain.

Younger women compared to older women report significantly less satisfaction and more strain in the student role.

\section{Discussion of Findings}

These findings describe the educational concerns of women at two stages of the life-cycle. Older re-entry women tend to have higher family incomes and older children. They feel less financial pressure to advance at work or to find a new career. These older women are more likely to see re-entry as a form of personal development. Younger re-entry women show more career interest. Their lower family incomes and the financial demands of a young family may give them a financial incentive to return to school. Younger women may also want the security of their own careers, given the divorce rate in Canada today.

Generational difference may also explain the different reasons younger and 
Student Role Supports for Younger and Older Middle-Aged Women:

Application of a Life Event Model

older women give for re-entry. Older women may have a different view of work than younger women. The older woman today grew up at a time when a woman more typically raised a family and then returned to work. If she works today, she may see work as a way to earn income (especially for widows), a way to keep in touch with the world, or as a way to use her skills now that her children are grown. The younger woman was born after the Second World War and grew up with the dramatic increase in the labour force participation of women. She is more likely to accept the idea that a woman can have a career and raise a family. She may feel more committed to her career.

These findings also depict the younger woman, compared to the older woman, as more strained in her roles, more pressed by her children's demands and more pressed for time. These women frequently choose school because they want to move ahead in their careers, but they sacrifice relaxed family relationships, a feeling of ease at work and a general sense of well-being for academic achievement. The younger woman must juggle many roles and time commitments. She must fit school into an already busy schedule and she feels the strain of this juggling act.

Younger women appear to have fewer supports to help them cope with the stresses of university study. Younger women, compared to older women, felt they got little psychological support from their children for attending school. Young children probably felt that school left even less of their mother's time for them. Children of younger women, more often than the children of older women, felt negatively about their mothers going to school. Older women were more likely to have children who also attended university.

Other studies support this interpretation. Kelly (1982) found, for example, that older children give more positive support to their mothers than younger children. Younger children more often disapprove of their mothers studying. Re-entry women report that children make it hard for them to achieve their educational goals (Badenhoop \& Johansen, 1980).

Our findings and the reports in the literature help explain why younger women feel more strain than older women after re-entry. Studies show that strain increases when women lack support from friends and other family members. Children make more demands on younger women and they give these women little support. Younger married women indicate that their husbands help them with childcare, but this may explain some of the marital strain that these women report. Younger women are less likely to value the availability of night courses. A younger woman may feel guilty about spending evenings at school. Her young children want her at home and she also frequently has work 
commitments that take time from her family. Compared to the older woman, the younger woman may feel the need for greater support in her quest for academic advancement.

Older women often improve their family lives when they attend school. More than younger women, they find it helpful to have programs available at night, on Saturdays and off-campus. They also have older children and they may feel a stronger bond with these children after they re-enter university. The children and their mothers may have more interests in common. Older children can take pride in their mothers' achievements. All of this may reduce the strain that older re-entry women experience and may enhance their satisfaction in the student role.

\section{Targeted Institutional Supports}

Kasworm (1980) refers to the growing group of re-entry students as a "significant unique subculture within the traditional undergraduate environment" (p.32). Universities in the past have geared post-secondary programs to traditional-aged students (Fisher-Thompson, 1981). In recent years, however, educators and institutions have focused more attention on the needs of re-entry students.

The academic literature has begun to report on specific university programs and supports for re-entry students. For extensive reviews of proposed and existing institutional university supports, see Tittle and Denker (1980), Mulliken, Traeder, and Lack (1985), Hall and Gleaves (1981), and Holliday (1985). We will focus on those supports that, based on our findings, suit the needs of re-entry women. Most re-entry women could use most of the supports reviewed here; but some supports will be particularly useful to the most strained group - younger women with young families.

Our review divides support systems into three categories related to our conceptualization of re-entry as a self-initiated life event (see Figure 3). These categories are:

1. Motivation

2. Coping

3. Adaptation 
Figure 3

\begin{tabular}{|l|}
\hline \multicolumn{1}{|c|}{$\begin{array}{c}\text { Re-entry as } \\
\text { Self-Initiated } \\
\text { Life Event }\end{array}$} \\
\hline \multicolumn{1}{|c|}{ Motivation } \\
Supports \\
\hline Information \\
Pre-admission \\
Counselling \\
Personal \\
Career \\
Academic \\
Financial Assistance \\
\hline
\end{tabular}

\begin{tabular}{|c|}
\hline $\begin{array}{c}\text { Resources/ } \\
\text { Coping }\end{array}$ \\
\hline Coping \\
Supports \\
\hline Information \\
Skills Development \\
Flexible Course \\
Scheduling \\
Spouse and Adult Child \\
Orientation \\
Counselling \\
Child Care \\
\hline
\end{tabular}

\begin{tabular}{|c|}
\hline \multicolumn{1}{|c|}{ Adaptation } \\
\\
\hline \multicolumn{1}{|c|}{ Adaptation } \\
Supports \\
\hline Academic Programs \\
Feminist Perspectives \\
Role Modeling \\
Social Space and Peer \\
Functions \\
Inclusive University \\
Culture \\
Mature Student \\
Centres \\
\hline
\end{tabular}

Figure 3. Educational re-entry for middle-aged women: Modified life event model related to institutional supports. Adapted and elaborated from "The Psychological Construction of the Life Span" by S.K. Whitbourne, 1985, in J.E. Birren, K.W. Schaie Handbook of the Psychology of Aging, New York: Van Nostrand Reinhold, p. 600. Copyright 1985 Van Nostrand Reinhold. Reprinted by permission.

1. Motivation. Recruitment supports help mature women decide whether or not to return to school. What types of supports best meet this need?

First, women need sound information about the university and its programs. Women also need to find this information easily. Weinstein (1981) suggests that schools distribute information at supermarkets, churches and other central locations. The university should present itself as interested in enroling re-entry women. Universities with support systems that help re-entry women will present this image best. Universities should advertise the existence of support programs. Universities should also recognize that younger and older re-entry women return to school for different-reasons. Schools can target their promotions to these different needs. This may increase the numbers of middleaged women who return to school.

Second, Campbell (1984) and Goldberg (1980) stress the importance of expert counselling for adult students. Most re-entry women enrol as part-time students. This means that those who plan to get a degree will take longer than usual to finish. Re-entry students need help in course selection and program choice. 
Pre-admission counsellors should also know about the life-cycle related stresses re-entry women face. Younger re-entry women, for example, face unique pressures due to role conflicts. Women aged 30 to 50 give lack of time due to family responsibilities as the major reason for not resuming their education (Cross, 1979). An advisor can discuss time and family pressures with the student. The advisor can then help the student plan a schedule and course load. This type of advising may be the most important support the university can offer.

Many re-entry women need career counselling. A number of studies (Apps, 1981; Astin, 1976; Felmlee, 1988; McCrea, 1979; Smart \& Pascarella, 1987) report that women re-enter school to advance their careers or to find work. Our study shows that younger re-entry women have the greatest interest in career advancement. These younger women are likely to find pre-admission career counselling particularly useful.

Our study found that older women, more often than younger women, return to school for self-development. They may also want to escape loneliness and low self-esteem (Hall \& Gleaves, 1981). Some older re-entry women want to find a career to supplement their incomes. Older women may need counselling to help them clarify their goals. This would give these women a clearer sense of purpose and should help motivate them to continue their studies once they enrol.

Mohsenin (1980) reports on an innovative form of peer pre-admission support. A large land grant university in the United States ran this program for two consecutive years. Re-entry women who already took classes at the university planned conferences for women in the community. The conferences used re-entry women as guest speakers. These speakers served as role models for potential students who attended the sessions. Small group discussions appeared to have the most positive impact.

Third, studies report on the need for financial support for re-entry students (Apps, 1981; Dunkle, 1981; Smallwood, 1980; Solmon \& Goirdon, 1981). The women in our study did not tend to use financial assistance. Most of them had middle-class family incomes. However, availability of financial support could recruit more needy students. Also, most financial supports do not apply to students who take only one or two courses. New financial aid policies could help more women from more diverse economic backgrounds return to school.

2. Coping. The project on the Status and Education of Women in the United States (Fisher-Thompson, 1981) focused attention on re-entry programs. They define a re-entry program as one that helps the returning student adjust to campus life. Re-entry programs let students know what supports exist at the 
university. Students can then choose the supports that meet their needs. This constitutes the first and most basic coping support.

Second, basic skills courses in reading, mathematics, writing, test-taking and library techniques can help returning students. Re-entry women express concern about their long absences from school. This applied particularly to older reentry women who have been out of school the longest. These women also doubt their skills (Novak \& Thacker, in press; Prahl, 1981). Students who have been out of school for a long time sometimes need basic skills courses to build confidence.

Basic skills courses exist at most universities and re-entry women can benefit from these courses. The university needs to promote these courses among reentry students. The university also needs to offer these courses at a time that fits the re-entry woman's schedule. This may mean setting up special sections of these courses in the evenings or on weekends.

Third, re-entry women benefit from course schedules designed to meet their needs. Women who work outside the home and women with young children often need alternatives to the standard day or evening classes. Alverno College, for example, offers a Weekend College for re-entry women. This program offers compact and intensive week-end classes that allow a student to complete a degree over a four-year period (Salem \& Sharkey, 1985).

Fourth, universities can help orient students' spouses to university life. Married women report that they find psychological support of their spouses helpful (Berkove, 1979; Markus, 1977; Rice, 1979). Husbands may give more support to re-entry women if they understand the demands placed on their wives as students. The university can sponsor social functions that inform husbands about university life. The university can also involve older children in these social functions. Psychological support from older children can help a woman cope with the stress of school re-entry (Novak \& Thacker, in press).

Fifth, Ballmer and Cozby (1981) say that re-entry women benefit from counselling on how returning to school affects family life. Beutell and O'Hare (1987) further suggest that workshops and presentations at the start of a re-entry woman's schooling include strategies for coping with stress. We suggest that early adjustment counselling include children and husbands when possible.

Counsellors should know about the multiple role demands that re-entry women face. Markus (1977) reports that almost half of the re-entry women she studied dropped out a least once. Most often the women gave demands outside of school as the reason for dropping out. Flannery and Apps (1987) studied middle-aged graduate students' stress. They found that difficulties in balancing 
school and family time only increase as students progress. They also show that re-entry women rate this problem as significantly more serious than do re-entry men. Counsellors should also help women plan for careers after graduation. Peer counselling may be useful in this regard.

Re-entry women need varied supports to help them stay in school. They also need advice and guidance as they continue in a program. Women who take many years to complete their degrees especially need this kind of academic advising. Part-time students with young children, or women who work, need counselling outside the normal nine-to-five work day.

Sixth, younger women with younger children need affordable day care. This would allow many of them to take day courses and to take more courses each year. More than three-quarters of re-entry women in our study report that they would take more courses if they could. Younger women report more help with child care from their spouses; however, they also report less psychological support from spouses. More child care might ease some of the family tensions that result from a woman's return to school.

Child care can help relieve the pressures of child rearing, but programs must meet the needs of the re-entry, part-time learner. Day care programs often give preference to children who attend full-time. However, part-time re-entry women may only need a few hours of day care at a time. In addition, day care rarely meets the needs of women with older children. More flexible child care hours, better access to child care and more appropriate child care for older children would help re-entry women.

3. Adaptation. We have used satisfaction as an indicator of positive adaptation to the student role. Universities can do a great deal to enhance the academic satisfaction of re-entry women. Research shows that mature students score higher on cognitive interest than younger students (Wolfgang \& Dowling, 1981). Solmon and Gordon (1981) report that adults enjoy the more academic side of school life. Re-entry women tend to have more self-motivation than younger women (Badenhoop \& Johansen, 1980). Universities can offer programs that satisfy and encourage this academic orientation.

Older women consider their life experiences to be a valued adjunct to their student role. Some new curricula recognize this. They include the study of women's lives from a feminist perspective. These courses make the learner an active participant in the classroom (Shuster \& Van Dyne, 1984). McLaren (1987) says that feminist reforms in adult education help re-entry women 
improve their social position. Researchers need to study the effects of feminist education on the quality of the re-entry woman's student.life. For example, programs like those of Alverno College deserve further study (Salem \& Sharkey, 1985).

Studies show that re-entry women sometimes model themselves on their teachers (Bennett, Walker, Rohaly \& Hopkins, 1981; Guppy, Balson, \& Velutini, 1987). One re-entry woman said to the female investigator after a presentation of our study, "Seeing you up there made me think that I could do something, too." Female professors can recognize and support the tendency of re-entry women to see them as role models.

The university can provide spaces where re-entry women can meet and share their experiences. These meetings can help re-entry women make friends and gain psychological support (Speer \& Dorfman, 1986). Cafeterias, coffee shops and beer bashes cater to the young, unmarried and childless student. Re-entry women may need other kinds of places to meet. This could include seminars, discussion groups, guest lectures or arts programs that meet their intellectual. needs. This would help re-entry women adjust to university life and it would help them enjoy their education more.

Many re-entry women say that they feel they don't belong in the university. They feel out of step, out of time. They feel that this is not their institution (see Giesler \& Thrush, 1975; Markust, 1977; Peterson \& Associates, 1979). The university culture needs reform.

Continuing education centres for women incorporate many of the supports mentioned above; however, few post-secondary institutions have such centres. Larger schools more often have these centres than smaller schools (Tittle \& Denker, 1980). Those schools without centres must choose supports most needed by re-entry women. We have suggested some useful supports that fit the life-cycle stages of mature re-entry women.

Students of all ages need to feel that the university values their contribution. Re-entry women tend to have demanding family and work role commitments outside the university. These women bring their life experience to the classroom. Universities need to find ways of using the talents and knowledge of these women. The University can begin by providing re-entry women with the institutional supports they need to re-enter university and to successfully complete their programs. 


\section{Summary and Conclusion}

This study conceptualized educational re-entry as a self-initiated life event and proposed an elaborated life event model to understand re-entry motivations, stresses, coping and adaptation.

The study shows that middle-aged re-entry women form at least two subgroups - those at an earlier life-cycle stage and those at a later life-cycle stage. We found that each of these groups gave somewhat different reasons for returning to school, faced different problems at school, and needed different types of supports.

Younger middle-aged women, compared to older women, faced the greatest strain upon returning to school. They also had the greatest need for supports. We reviewed the social supports for re-entry women reported in the literature and conceptualized these supports in terms of our modified life event model. We found that some supports serve all re-entry women. Our study suggests that younger re-entry women need special supports to meet their needs. Proper supports will help more middle-aged women enter university. Supports will also help these women stay in school and complete their programs.

\section{REFERENCES}

Apps, J.W. (1981). The adult learner on campus: A guide for instructors and administrators. Chicago: Follett Publishing Company.

Astin, H.S. (1976). Adult development and education. In H.S. Astin (Ed.), Some action of her own: the adult woman and higher education (pp. 45-56). Toronto: D.C. Heath and Company.

Badenhoop, M.S., \& Johansen, M.K. (1980). Do reentry women have special needs? Psychology of Women Quarterly, 4, 591-595.

Ballmer, H., \& Cozby, P.C. (1981). Family environments of women who return to college. Sex Roles, Z,1019-1026.

Belanger, R., \& Omiecinski, T. (1987). Part-time university enrollment. Canadian Social Trends. Summer, 22-25.

Bennett, S.M., Walker, W.E., Rohaly, K. \& Hopkins, J.H. (1981). Factors in programming college experiences for women. Journal of the National Association for Women Deans, Administrators and Counselors, 44, 29-36.

Berkove, G.F. (1979). Perceptions of husband support by returning women students. The Family Coordinator, 28, 451-457.

Beutell, N.J., \& O'Hare, M.M. (1987). Coping with role conflict among returning students: Professional versus non-professional women. Journal of College Student Personnel, $\underline{28}, 141-145$. 
Breneman, D. W. (1983). The coming enrollment crisis: Focusing on the figures. Change, March, 14-19.

Brooks-Gunn, J., \& Kirsh, B. (1984). Life events and the boundaries of midlife for women. In G. Baruch \& J. Brooks-Gunn (Eds.) Women in midlife (pp. 11-30). New York: Plenum.

Campbell, D.D. (1984). The new majority: Adult learners in the university. Edmonton: The University of Alberta Press.

Campbell, M.D., Wilson, L.G., \& Hanson, G.R. (1980). The invisible minority: A study of adult university students. Final report submitted to the Hogg Foundation for Mental Health. Austin: Office of the Dean of Students, University of Texas.

Carnegie Council on Policy Studies in Higher Education (1981). Three thousand futures. San Francisco: Jossey-Bass.

Carp, A., Peterson, R., \& Roelfs, P. (1976). Adult learning interests and experiences. In K.P. Cross, J.R. Valley \& Associates, Planning non-traditional programs (pp. 11 52). San Francisco: Jossey-Bass.

Crimmins, E.M., \& Riddler, E.W. (1985). College enrollment trends among the population thirty-five and older: $1972-1982$ and projections to 2000. Educational Gerontology. $\underline{1}, 363-385$.

Cross, K.P. (1979). Adult learners: Characteristics, needs, and interests. In R.E. Peterson \& Associates, Lifelong learning in America (pp.75-141). San Francisco: JosseyBass.

Cross, K.P. (1981) Adults as learners. San Francisco: Jossey-Bass.

Devereaux, M.S. (1985). One in every five: A survey of adult education in Canada. Published jointly by Statistics Canada and Education Support Sector, Department of the Secretary of State. Minister of Supply and Services Canada.

Dunkle, M.C. (1981). Financial aid: Helping re-entry women pay college costs. Project on the status and education of women. Washington, D.C.: Association of American Colleges.

Felmlee, D. H. (1988). Returning to school and women's occupational attainment. Sociology of Education, 61, 29-41.

Fisher-Thompson, J. (1981). An overview of re-entry women: Meeting the enrollment challenge. Project on the status and education of women. Washington D.C.: Association of American Colleges.

Flannery, D., \& Apps, J. (1987). Characteristics and problems of older returning students. College of Agricultural \& Life Sciences Research Report. University of Wisconsin-Madison.

Frances, C. (1980). College enrollment trends: Testing the conventional wisdom against the facts. Prepared for the Association Council for Policy Analysis and Research. Washington, D.C.: American Council on Education.

Geisler, M.P., \& Thrush, R.S. (1975). Counseling experiences and needs of older women students. Journal of the National Association for Women Deans, Administrators and Counselors, Fall, 3-8. 
George, L.K. (1980). Role transitions in later life. Belmont, California: Wadsworth.

Glenny, L. A. (1980). Demographic and related issues for higher education in the 1980's. Journal of Higher Education, 51, 363-380.

Goldberg, J.C. (1980). Counseling the adult learner: A selective review of the literature. Adult Education, $30,67-81$.

Gore, S. (1984). Stress-buffering functions of social supports: An appraisal and clarification of research models. In B.S. Dohrenwend \& B.P. Dohrenwend (Eds.), Stressful life events and their contexts (pp. 202-222). New Brunswick, New Jersey: Rutgers University Press.

Gould, R.L. (1978). Transformations: Growth and change in adult life. New York: Simon \& Schuster.

Guppy, N., Balson, D., \& Vellutini, S. (1987). Women and higher education in Canadian society. In J.S. Gaskell \& A.T. McLaren (Eds.), Women and education: A Canadian perspective (pp. 171-192). Calgary: Detselig Enterprises Limited.

Hall, R.M., \& Gleaves, F.D. (1981). Re-entry women: Special programs for special populations. Project on the status and education of women. Washington, D.C.: Association of American Colleges.

Holliday, G. (1985). Addressing the concerns of returning women students. In N.J. Evans (Ed.), New directions for student services: Facilitating the development of women. no. 29, March, 61-73.

Hultsch, D.F., \& Deutsch, F. (1981). Adult development and aging: A life-span perspective. New York: McGraw-Hill.

Kasworm, C.E. (1980). The older student as an undergraduate. Adult Education, 3I, 3047.

Kelly, S. (1982). Changing parent-child relationships: An outcome of mother returning to college. Family Relations, 31, 287-294.

Kirk, C.F., \& Dorfman, L.T. (1983). Satisfaction and role strain among middle-age and older reentry women students. Educational Gerontology, 9, 15-29.

Lazarus, R.S. (1981). The stress and coping paradigm. In C. Eisdorfer, D. Cohen, A. Kleinman \& P. Maxim (Eds.), Models for clinical psychopathology (pp. 177-214). New York: Spectrum.

Levinson, D.J. (1978). The seasons of a man's life. New York: Knopf.

Lin, N., Simeone, R. S., Ensel, W., \& Kuo, W. (1979). Social support, stressful life events and illness: A model and empirical test. Journal of Health and Social Behavior, 20, 108-119.

Markus, H. (1977). Continuing education for women: Factors influencing a return to school and the school experience. In J. Pottker \& A. Fishel (Eds.), Sex bias in the schools: The research evidence (pp. 354-379). Cranbury, New Jersey: Associated University Presses, Inc.

McCrea, J.M. (1979). The new student body: Women returning to college. Journal of the National Association for Women Deans, Administrators and Counselors, 43, 13-19. 
McLaren, A.T. (1987). Rethinking "femininity": Women in adult education. In J.S. Gaskell \& A.T. McLaren (Eds.), Women and education: A Canadian perspective (pp. 333-350). Calgary: Detselig Enterprises Limited.

Mechanic, D. (1974). Social structure and personal adaptation: Some neglected dimensions. In G:V. Coelho, D. Hamburg \& J. Adams (Eds.), Coping and adaptation (pp. 32-44). New York: Basic Books.

Mohsenin, I.C. (1980). Peer-sponsored conference: College re-entry strategy for adult women. Educational Horizons, 58 , 193-196.

Mulliken, E.Y., Traeder, M., \& Lack, A.E. (1985). The rewarding challenge: Welcoming re-entry students to the small college. Newton, Massachusetts: WEEA Publishing Center.

Neugarten, B.L., \& Datan, N. (1973). Sociological perspectives on the life cycle. In P.B. Baltes \& K.W. Schaie (Eds.), Life-span developmental psychology: Personality and socialization (pp. 53-69). New York: Academic Press.

Novak, M., \& Thacker, C. (in press). Satisfaction and strain among middle-aged women who return to school: Replication and extension of findings in a Canadian context. Educational Gerontology.

Parliament, J. (1986). Education in Canada: Selected highlights. Canadian Social Trends, Autumn, 15-20.

Pearlin, L.I., \& Schooler, C. (1978). The structure of coping. Journal of Health and Social Behavior, 19, 2-21.

Peterson, R.E., \& Associates (1979). Lifelong learning in America. San Francisco: Jossey-Bass.

Prahl, E. (1981). Confidence and competence: Basic skills programs and refresher courses for re-entry women. Project on the status and education of women. Washington, D.C.: Association of American Colleges.

Rice, J.K. (1979). Self-esteem, sex-role orientation, and perceived spouse support for a return to school. Adult Education, 29, 215-233.

Riegel, K.F. (1975). Adult life crises: A dialectic interpretation of development. In N. Datan \& L.H. Ginsberg (Eds.), Life-span developmental psychology: Normative life crises (pp. 99-128). New York: Academic Press.

Salem, G., \& Sharkey, S. (1985). Transforming the social sciences. In M.R. Shuster \& S.R. Van Dyne (Eds.), Women's place in the academy: Transforming the liberal arts curriculum (pp. 232-257). Totowa, New Jersey: Rowman and Allenheld.

Schlossberg, N.K. (1984). The midlife woman as student. In G. Baruch and J. BrooksGunn (Eds.), Women in midlife (pp. 315-339). New York: Plenum Press.

Selye, H. (1975). Stress without distress. New York: New American Library.

Sheehy, G. (1976). Passages: Predictable crises of adult life. New York: Bantam.

Sheehy, G. (1981). Pathfinders. New York: Bantam.

Shuster, M., \& Van Dyne, S. (1984). Placing women in the liberal arts: Stages of curriculum transformation. Harvard Educational Review, 54, 413-428. 
Shuster, M.R., \& Van Dyne, S. R. (1985). Stages of curriculum transformation. In M.R. Shuster \& S.R. Van Dyne (Eds.), Women's place in the academy: Transforming the liberal arts curriculum (pp. 13-29). Totowa, New Jersey: Rowman and Allenheld.

Smallwood, K.B. (1980). What do adult women college students really need? Journal of College Student Personnel, 21, 65-73.

Smart, J.C., \& Pascarella, E.T. (1987). Influences on the intention to reenter higher education. Journal of Higher Education, $\underline{58}$, 306-322.

Solmon, L.C., \& Gordon, J.J. (1981). The characteristics and needs of adults in postsecondary education. Lexington, Massachusetts: D.C. Heath and Company.

Speer, L.J., \& Dorfman, L.T. (1986). The outcomes of reentry education: Personal and professional development in middle-aged and older women graduates. Educational Gerontology, 12, 253-265.

Tittle, C.K., \& Denker, E.R. (1980). Returning women students in higher education: Defining policy issues. New York: Praeger.

Weinstein, L. (1981). Recruitment and admissions: Opening the door for re-entry women. Project on the status and education of women. Washington, D.C.: Association of American Colleges.

Whitbourne, S.K. (1985). The psychological construction of the life span. In J.E. Birren \& K. W. Schaie (Eds.), Handbook of the psychology of aging. (pp. 594-618). 2nd ed. New York: Van Nostrand Reinhold.

Wolfgang, M.E., \& Dowling, W.D. (1981). Differences in motivation of adult and younger undergraduates. Journal of Higher Education, 52, 640-648. 